\title{
Comparative pathogenicity of two strains of pike fry rhabdovirus and spring viremia of carp virus for young roach, common carp, grass carp and rainbow trout
}

\author{
O. L. M. Haenen, A. Davidse \\ Central Veterinary Institute, PO Box 65, 8200 AB Lelystad, The Netherlands
}

\begin{abstract}
A field isolate of pike fry rhabdovirus (PFR-80560) isolated from roach was tested for pathogenicity in fry of roach Rutilus rutilus L., common carp Cyprinus carpio L., grass carp Ctenopharyngodon idella Valenciennes and rainbow trout Oncorhynchus mykiss Richardson. The fish were experimentally exposed to the virus by immersion in a virus-seeded water-bath. We also compared the pathogenicity of PFR-80560 with that of reference strains of PFR and spring viremia of carp virus (SVCV). The PFR-80560 isolate was highly pathogenic for roach, common carp and grass carp, but not for rainbow trout. Although the PFR reference strain was mildly pathogenic for roach, it was no longer pathogenic for pike fry which may represent attenuation due to its numerous passages in cell culture. The SVCV was highly pathogenic for common carp, mildly pathogenic for roach and grass carp, but not pathogenic for rainbow trout. It was concluded that since the PFR-80560 isolate was capable of infecting all the cyprinids tested, it should be considered as a threat to cyprinid fish farms.
\end{abstract}

\section{INTRODUCTION}

Pike fry rhabdovirus (PFR) causes an acute disease in pike fry Esox lucius L. (de Kinkelin et al. 1973). The virus has not only been isolated from pike fry (Bootsma \& van Vorstenbosch 1973, de Kinkelin et al. 1973, Bekesi et al. 1984), but also from grass carp Ctenopharyngodon idella Valenciennes (Ahne 1975, 1986), tench Tinca tinca L., white bream Blicca bjoerkna L. (Ahne et al. 1982), sheatfish Silurus glanis (Jørgensen et al. 1989), Pseudorasbora parva (Ahne \& Thomsen 1986), and brown trout Salmo trutta (Adair \& McLoughlin 1986). In 1989, we isolated PFR (no. 80560) from roach Rutilus rutilus L. (Haenen \& Davidse, 1989) during routine certification procedures. The subadult roach, from which we isolated the PFR (no. 80560) had no clinical signs of disease. This isolate could not be distinguished from the PFR reference strain by neutralization test, but it was distinguishable from the spring viremia of carp virus (SVCV) a serologically related rhabdovirus (Haenen \& Davidse 1989).

Common carp Cyprinus carpio L. grass carp, and rainbow trout Oncorhynchus mykiss Richardson are commercially cultured fish species of economic importance. To investigate the potential hazard of our field PFR isolate for carp and rainbow trout, we compared its pathogenicity to that of reference strains of PFR and SVCV (Fijan et al. 1971, de Kinkelin et al. 1973, Bachmann \& Ahne 1974, Ahne 1986, Jørgensen et al. 1989). Fry of 4 freshwater fish species were experimentally infected by immersing them in water containing virus (Bootsma et al. 1975, Ahne 1978). Fry of roach were tested to determine whether or not PFR-80560 was species-adapted.

\section{MATERIALS AND METHODS}

Cell culture and viruses. Fathead minnow (FHM) cells were grown at $30^{\circ} \mathrm{C}$ with Eagle's minimal essential medium with Hanks' salts (HMEM), supplemented with $5 \%$ foetal calf serum (FCS), $2 \mathrm{mM} \mathrm{L-glutamine,}$ $90 \mathrm{IU}$ penicillin $\mathrm{ml}^{-1}$, and $40 \mathrm{ng}$ kanamycin $\mathrm{ml}^{-1}$.

The PFR-80560 isolate was obtained from subadult 
roach at our institute in February 1989. This isolate was passaged 6 times in FHM cells at $20^{\circ} \mathrm{C}$ according to the methods of de Kinkelin et al. (1973) and de Kinkelin et al. (1974). The PFR reference virus was obtained from Dr Barry Hill, Weymouth, England, and had been passaged 15 times in FHM cells. The SVCV reference strain, obtained from Dr Winifried Ahne, Munich, Germany, had undergone 16 passages in FHM cells.

Confluent monolayers of FHM cells in $175 \mathrm{~cm}^{2}$ flasks were inoculated with $10 \mathrm{ml}$ of a virus suspension containing $100 \mathrm{TCID}_{50} \mathrm{ml}^{-1}$, the diluent being maintenance medium composed of Eagle's minimal essential medium with Earle's salts (EMEM), supplemented with $2 \%$ FCS, 2 mM L-glutamine, 90 IU penicillin $\mathrm{ml}^{-1}$, and $40 \mathrm{ng}$ kanamycin $\mathrm{ml}^{-\mathrm{i}}$. After a $1 \mathrm{~h}$ adsorption period at $20^{\circ} \mathrm{C}, 25 \mathrm{ml}$ of maintenance medium were then added and the flasks were incubated at $20^{\circ} \mathrm{C}$ until cytopathology was complete. Cells and medium were centrifuged for $10 \mathrm{~min}$ at $2000 \times \mathrm{g}$ at $4{ }^{\circ} \mathrm{C}$, and the supernatant was collected and stored at $-70^{\circ} \mathrm{C}$. The viruses were titrated on FHM cell monolayers as described by Hedrick et al. (1978).

Animals and experimental design. Fish used in these experiments were of the following sizes: roach fry $(1.8 \pm 0.1 \mathrm{~cm})$, common carp fry $(3.0 \pm 0.2 \mathrm{~cm})$, grass carp fry $(2.8 \pm 0.2 \mathrm{~cm})$, rainbow trout fry $(4.0 \pm 0.1 \mathrm{~cm})$ and pike fry $(2.8 \pm 0.2 \mathrm{~cm})$. Additionally, groups of pike eggs (>1000 group $^{-1}$ ), were exposed to virus using the same method. Each experiment was carried out once. Before the start of an experiment, 20 fish per species were sacrificed and examined for the presence of pathogens. Fresh smears of skin mucus, gills and gut contents were examined for parasites. Whole fish were pooled, ground up, and examined for virus by standard isolation procedures using FHM cells held at 15, 20 and $28^{\circ} \mathrm{C}$. The fish had no signs of disease and neither parasites (protozoa and metazoa) nor fish viruses were detected.

To infect the fish, groups of 250 fish were exposed to aerated water containing one of the viruses at a final concentration of $10^{58} \mathrm{TCID}_{50} \mathrm{ml}^{-1}$. Equivalent control groups were exposed to aerated water receiving maintenance medium only. The water in each aquarium, which was equipped with an internal biological filter, was totally renewed after $1 \mathrm{~h}$. Water temperatures varied between 14 and $20^{\circ} \mathrm{C}$ during the experiments

Fish were fed daily with virus-free commercial trout food or live zooplankton Artemia spp. The water in each aquarium was renewed 3 to 4 times a week and waste water was disinfected with $2 \% \mathrm{NaOH}$ for at least $1 \mathrm{~h}$ (Ahne 1982). Clinical signs of disease, mortality, and water temperatures were recorded daily, and dead fish were removed for virus isolation. Once a week, 5 fish were collected from each tank and pooled for virus isolation and 5 others were used for histopathologic examination.

Mean water temperatures varied over time between 14 and $20^{\circ} \mathrm{C}$, and were $17.7^{\circ} \mathrm{C}$ for roach, $16.9^{\circ} \mathrm{C}$ for common carp, $16.9^{\circ} \mathrm{C}$ for grass carp and $17.5^{\circ} \mathrm{C}$ for rainbow trout.

Virus examination. For virus isolation, dead fish were collected daily, pooled, weighed and ground with a mortar and pestle, and a $10 \%$ suspension (w/v) was made in maintenance medium. The homogenates were incubated at $20^{\circ} \mathrm{C}$ for $1 \mathrm{~h}$ and then centrifuged at 3000 $\times g$ for $10 \mathrm{~min}$ at $4{ }^{\circ} \mathrm{C}$. The supernatant was collected and diluted 1:10 in medium (EMEM, $2 \%$ FCS, $2 \mathrm{mM}$ glutamine, $90 \mathrm{IU}$ penicillin $\mathrm{ml}^{-1}$ and $40 \mathrm{ng}$ kanamycin $\mathrm{ml}^{-1}$ ). Fathead minnow cell monolayers in $25 \mathrm{~cm}^{2}$ tlasks were inoculated with $2 \mathrm{ml}$ of the diluted sample and incubated $1 \mathrm{~h}$ at $20^{\circ} \mathrm{C}$ to adsorb the virus. The monolayers were then washed 3 times with medium, and $5 \mathrm{ml}$ of maintenance medium were added. Flasks were incubated at $20^{\circ} \mathrm{C}$ for $7 \mathrm{~d}$ and examined daily for cytopathogenic effect (CPE). When CPE was $100 \%$, cells and medium were harvested and stored at $-70^{\circ} \mathrm{C}$. Positive samples were titrated on FHM cells as described above. If no CPE was observed after $7 \mathrm{~d}$, the sample was blind passaged onto fresh FHM monolayers and observed for an additional $7 \mathrm{~d}$.

Histopathology and statistical analysis. Fish were fixed for histopathology in $4 \%$ buffered formaldehyde. After fixation, fish were embedded in paraffin and $5 \mu \mathrm{m}$ sections cut on a microtome. Sections were placed on glass slides and stained with haematoxylin and eosin. The stained sections were examined by light microscopy.

The $\chi^{2}$ statistical analysis $(p<0.05)$ was used to compare the mortalities of the virus treated groups with those of the control groups. Each fish species was analyzed as a separate group.

\section{RESULTS}

\section{Experimental infection of roach}

The PFR-80560 isolate was highly pathogenic for roach killing $85.2 \%$ of the exposed fish between Days 3 and 7 (Fig. 1). The virus also produced severe pathological changes (Table 1), and high virus titers were seen in the infected fish (Table 2). The PFR reference strain was less pathogenic causing only a $24.9 \%$ mortality by Day 35 . Virus could be isolated during the period in which mortality was occurring, but pathological changes were not observed until Day 10 (Table 3). The SVCV isolate caused a $38 \%$ mortality in roach by Day 35 , which was accompanied by pathological changes. The period of virus isolation exceeded the time during 


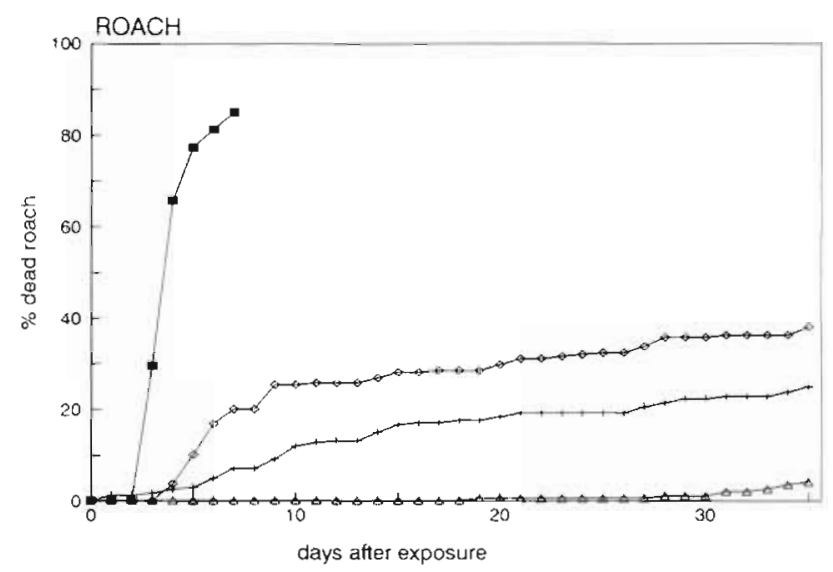

Fig. 1 Rutilus rutilus. Mortality (\%) of fry of roach after bath exposure to PFR-80560 (a), PFR-ref $(+)$ or SVCV-ref $(\diamond)$. The control group $(\triangle)$ was exposed in the same way but without virus

which pathological changes and mortalities were observed (Table 3 ). The mortality among the group infected with PFR-80560 was significantly higher than the mortality among the SVCV-infected group (Fig. 1).

\section{Experimental infection of common carp}

The PFR-80560 isolate was pathogenic for common carp as $45.4 \%$ of this species had died by Day 35 (Fig. 2). The mortalities were associated with virus isolations and pathological changes. Virus could still be isolated at Day 35. The PFR reference virus was not pathogenic for common carp as only $4.0 \%$ of the fish had died by Day 35; however, virus could be isolated up to Day 31 (Table 3). The SVCV isolate was highly pathogenic for common carp, causing a $97.7 \%$ mortality by Day 35. Again, mortality was associated with high virus titers (Table 2) and pathological changes (Table 1) and the virus positive period exceeded that of pathological changes and mortality as virus could be isolated up to Day 34 post-exposure (Table 3). The group infected with SVCV had a significantly higher mortality than the group infected with PFR-80560 $(p<0.05)$. Mortalities in the control group were insignificant.

\section{Experimental infection of grass carp}

The PFR-80560 isolate was mildly pathogenic for grass carp, causing an $18.3 \%$ mortality by Day 35 . Mortalities were associated with virus isolation and pathological changes and virus could still be isolated at Day 35 (Table 3). As with common carp, the PFR reference virus was not pathogenic for grass carp. Only $4.0 \%$ of the fish had died by Day 35 and only one fish

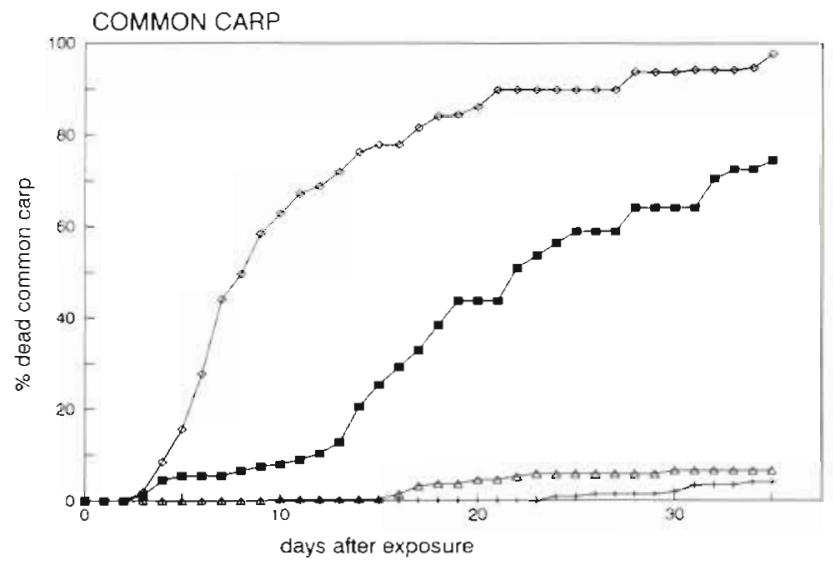

Fig. 2. Cyprinus carpio. Mortality (\%) of fry of common carp after bath exposure to PFR-80560 (无, PFR-ref (+), or SVCVref $(\diamond)$. The control group $(\Delta)$ was handled in the same way but without virus

showed pathological changes at Day 14 (Table 3). The SVCV isolate was mildly pathogenic for grass carp causing an $14.9 \%$ mortality by Day 35. There were no mortalities after Day 12, but fish with clinical signs of disease were observed and virus could be isolated until Day 29 (Table 3). The groups infected with PFR80560 and SVCV respectively had significantly higher mortality rates than the control group ( $p<0.05)$. No significant differences were found between the mortalities of the PFR reference virus-infected group and the control group, or between those of the PFR-80560 and SVCV-infected groups.

\section{Rainbow trout}

The PFR-80560, PFR-reference, and SVCV strains did not produce significant mortalities in rainbow trout $(p<0.05)$. Although virus could be isolated for a short period ( 2 wk or less), no pathological changes were observed (Table 3 ).

\section{Pike fry}

As a positive control for the PFR-reference virus (Bootsma et al. 1975), we exposed pike eggs and pike fry with the PFR-reference virus in the same way as the other groups. Another group of pike eggs and pike fry were exposed to PFR-80560. Cannibalism was pronounced in the pike groups, so their numbers decreased rapidly. However, no hydrocephalus or other clinical signs described by Bootsma (1971) were seen in any of the virus-infected groups. These groups did not show an increased mortality compared with uninfected fish. We isolated the PFR reference virus and PFR-80560 from Days 2 to 14 post-exposure. In both 
Table 1. Pathological signs of disease observed in virus-infected fish

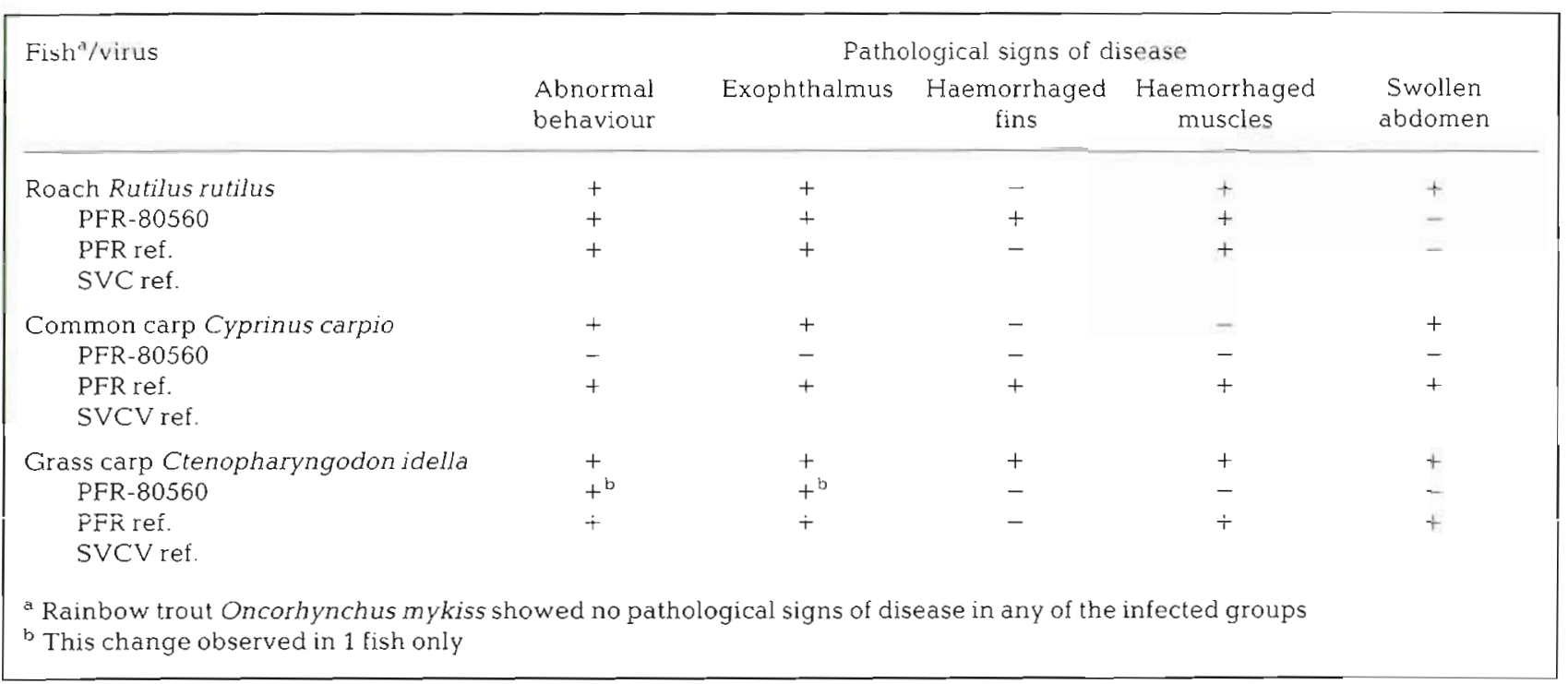

Table 2. Virus titers $\log \mathrm{TCID}_{50} \mathrm{ml}^{-1} 10 \% \mathrm{w} / \mathrm{v}$ suspension of fish fry infected with the PFR-80560 isolate or 2 other rhabdoviruses. Maximum detected virus titers are given

\begin{tabular}{lccc|}
\hline Fish & PFR-80560 & $\begin{array}{c}\text { Virus titer of fish infected with: } \\
\text { PFR ref. strain }\end{array}$ & SVCV ref. strain \\
\hline Roach Rutilus rutilus & 6.3 & 5.1 & 5.1 \\
Common carp Cyprinus carpio & 5.1 & $<1.6$ & 6.4 \\
Grass carp Ctenopharyngoden idella & 3.6 & $<1.6$ & $<1.6$ \\
Rainbow trout Oncorhynchus mykiss & 2.4 & $<1.6$ & $<1.6$ \\
\hline
\end{tabular}

Table 3. Days with virus and/or days with pathological changes. First number denotes the last day virus was recovered from exposed fish; second number(s) denote day post-exposure when pathological signs shown on Table 1 were observed

\begin{tabular}{|lcccc}
\hline Virus & $\begin{array}{c}\text { Roach } \\
\text { Rutilus rutilus }\end{array}$ & $\begin{array}{c}\text { Common carp } \\
\text { Cyprinus carpio }\end{array}$ & $\begin{array}{c}\text { Grass carp } \\
\text { Ctenopharyngodon } \\
\text { idella }\end{array}$ & $\begin{array}{c}\text { Rainbow trout } \\
\text { Oncorhynchus } \\
\text { mykiss }\end{array}$ \\
\hline PFR-strain 80560 & $7 / 3-7$ & $35 / 11-12$ & $35 / 5-35$ & $7 /-$ \\
PFR Ref. strain & $35 / 7-10$ & $31 /-$ & $14 / 14$ & $14 /-$ \\
SVCV Ref. strain & $29 / 4-7$ & $34 / 3-20$ & $29 / 7-29$ & $2 / 1$ \\
\hline
\end{tabular}

pike groups, decreasing virus titers were found over time.

Roach, infected with PFR-80560, had a significantly higher mortality than common carp and grass carp infected with the same virus. The SVCV isolate caused significantly higher mortalities in common carp than in roach and grass carp.

\section{Histopathology}

Histopathological examination of tissue sections verified the above findings (Table 1). Roach exposed to
PFR-80560 had severe haemorrhages over the entire body at Day 7, whereas roach exposed to the PFR reference strain showed no pathological changes. In the SVCV-infected group, there was a regression of the pancreas at Day 14.

Common carp exposed to PFR-80560 had haemorrhages in the kidney at Day 7 , and severe haemorrhaging in the muscle tissue. At Day 14, degeneration of the liver and kidney was observed. The group exposed to the PFR reference strain however, showed no pathological changes. Common carp infected with SVCV had severe haemorrhages at the fin bases by Day 7 and 

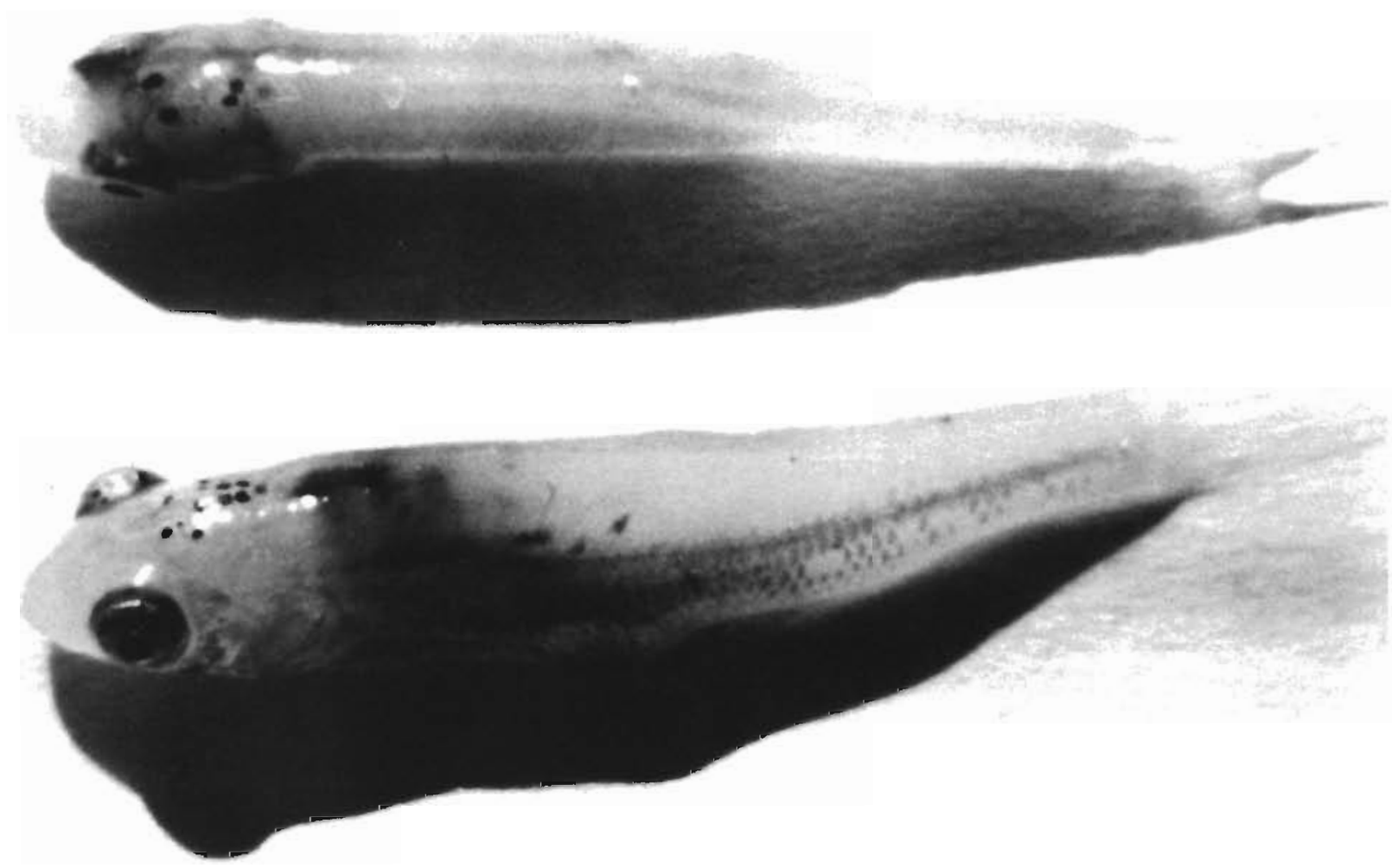

Fig. 3. Leuciscus idus var. auratus. Fry of golden ide 5 d after bath exposure to PFR-80560. The upper fish is a control, the lower fish shows both exophthalmus and haemorrhages in the muscles

by Day 14 they showed degeneration of the kidney and muscles.

Grass carp exposed to PFR-80560 had haemorrhages in the kidney at Day 21. No pathological changes were seen in grass carp exposed to PFR reference virus. Grass carp infected with SVCV had degeneration of the liver and spleen at Day 14 and at Day 21 showed regression of the spleen. No pathological signs were observed in any of the rainbow trout groups exposed to virus.

\section{DISCUSSION}

The PFR- 80560 isolated from roach was highly pathogenic for the cyprinids tested. In pilot experiments, in which we exposed fry of golden ide Leuciscus idus var. auratus (Cyprinid family) to this virus, $75.3 \%$ of the fry had died by Day 12 and pathological changes were observed (Fig. 3) and virus was isolated. PFR-80560 seems to be highly adapted to species of the Cyprinid family, as it was pathogenic for golden ide, common carp, grass carp, and roach, but not for rainbow trout (Salmonid family) or pike fry or eggs (Esocid family).

The pathogenicity of PFR-80560 was significantly higher than that of the PFR reference strain for the cyprinids tested $(p<0.05)$. When eggs and fry of pike were exposed to the PFR reference strain, no pathological changes were observed. Since the pike fry $(2.8 \mathrm{~cm})$ employed did not yet have a fully developed humoral immune system (Clerx 1978), they, and the pike eggs, were expected to be susceptible to PFR (Bootsma et al. 1975 ) however prolonged cultivation of the PFR reference strain on FHM cells may have caused a decrease in its pathogenicity for pike. Consequently it is difficult to compare the pathogenicity of PFR-80560 and the PFR reference strain for pike eggs and fry. Because PFR-80560 did not cause clinical signs or mortalities in pike fry, we conclude that it is not pathogenic for young pike.

The common carp group infected with SVCV, was a good positive control for the pathogenicity of SVCV. At a water temperature of $17^{\circ} \mathrm{C}$, the first pathological changes and mortalities were observed on Day 3 post- 
infection. This is earlier than reported by Ahne (1978). He infected 25 to $30 \mathrm{~g}$ carp with this virus and first detected a viraemia on Day 6 post-inoculation and noted the first mortality on Day 20 at a water temperature of $13^{\circ} \mathrm{C}$. These differences may be due to the different water temperatures $\left(17\right.$ vs $\left.13^{\circ} \mathrm{C}\right)$ and/or the different sizes and origins of the fish. The role of water temperature on SVCV infection was demonstrated by Badouy et al. (1980). Pathological changes, like those described by Negele (1977), were seen. Roach and grass carp were less susceptible to this cyprinid virus.

The wide host range of PFR was reported earlier (Ahne et al. 1982, Ahne \& Thomsen 1986). SVCV has also been isolated from crucian carp Carassius carassius (Kölbl 1975), bighead carp Hypophthalmichthys nobilis (Rudikov et al. 1975), and sheatfish Silurus glanis (Fijan et al. 1984). Our results agree with these findings that these viruses have wide host ranges.

None of the 3 viruses were pathogenic for rainbow trout although we did isolate low levels of virus from this species. It is possible that since we ground whole fish for virus isolation, we may simply have been detecting virus present on the skin of the fish. Our findings agree with those of Adair \& McLoughlin (1986) which indicate that rainbow trout fry are not susceptible to PFR.

Acknowledgements. We thank Drs Jorgensen, Dixon and colleagues who compared our PFRV isolate with the PFR and SVC reference viruses; Drs Hill and Ahne for providing the reference virus strains, and $H$. Dorsman, F. Keuzenkamp, N. Kuiper, J. Meijer, J. van Oirschot, and J. Pol for assisting with the experimental work and preparation of the manuscript.

\section{LITERATURE CITED}

Adair, B. M., McLoughlin, M. (1986). Isolation of Pike Fry Rhabdovirus from brown trout (Salmo trutta). Bull. Eur. Ass. Fish Pathol. 6 (3): 85

Ahne, W. (1975). A rhabdovirus isolated from grass carp (Ctenopharyngodon idella Val.). Arch. Virol. 48: 181-185

Ahne, W. (1978). Uptake and multiplication of spring viraemia of carp virus in carp. Cyprinus carpio L.. J. Fish Dis. 1: $265-268$

Ahne, W. (1982). Vergleichende Untersuchungen über die Stabilität von vier fischpathogener Viren (VHSV, PFR, SVCV, IPNV). Zbl. Vet. Med. Reihe B 29: 457-476

Ahne, W. (1986). Unterschiedliche biologische Eigenschaften 4 cyprinidenpathogener Rhabdovirusisolate. J. Vet. Med. Reihe B 33: 253-259

Ahne, W., Mahnel, H., Steinhagen, P. (1982). Isolation of Pike Fry Rhabdovirus from Blicca tench, Tinca tinca L., and white bream, Blicca bjoerkna L. J. Fish Dis. 5: 535-537

Ahne, W., Thomsen, I. (1986). Isolation of pike fry rhabdovirus from Pseudorasbora parva (Temminck \& Schlegel). J. Fish Dis. 9, (6): $555-556$

Bachmann, P. A., Ahne, W. (1974). Biological properties and identification of the agent causing swim bladder inflammation in carp. Arch. ges. Virusforsch. 44: 261-269

Badouy, A.-M., Danton, M., Merle, G. (1980). Virémie printanière de la carpe, résultats de contiminations expérimentales effectuées au printemps. Annis. Rech. vét. 11 (3): 245-249

Bekesi, L., Majoros, G., Szabo, E. (1984). Mass appearance of a rhabdovirus in pike fry (Esox lucius L.) in Hungary. Magy. Allatorv. Lapja 39 (4): 231-234

Bootsma, R. (1971). Hydrocephalus and red-disease in pike fry Esox lucius L. J. Fish Biol. 3: 417-419

Bootsma, R., de Kinkelin, P., Le Berre, M. (1975). Transmission experiments with pike fry (Esox lucius L.) rhabdovirus. $J$. Fish Biol. 7, 269-276

Bootsma, R., van Vorstenbosch, C. J. A. H. V. (1973). Detection of a bullet-shaped virus in kiudney sections of pike fry (Esox lucius L.) with red-disease. Neth. J. vet. Sci. 98; $86-90$

Clerx, J. P. M. (1978). Studies on pike fry rhabdovirus and the immunoglobulin of pike (Esox lucius). Ch. 8: Pike immunoglobulin: occurrence in eggs and ontogeny in fry; Dissertation, Veterinary Faculty, Univ. of Utrecht J. H. Pasmans, The Hague, 90-98

de Kinkelin, P., Galimard, B., Bootsma, R. (1973). Isolation and identification of the causative agent of 'red disease' of pike (Esox lucius L., 1766). Nature 241: 465-467

de Kinkelin, P., Le Berre, M., Galimard, B. (1974). Rhabdovirus des poissons. I. Propriétés in vitro du virus de la maladie rouge de l'alevin de brochet. Annls. Microbiol. (Inst. Pasteur, Paris) 125 A: 93-111

Fijan, N., Matasin, Z., Jeney, Z., Olah, J., Zwillenberg, L. O. (1984). Isolation of rhabdovirus carpio from sheatfish (Silurus glanis) fry. Symp. biol. Hung. 23: 17-24

Fijan, N., Petrinec, Z., Sulimanovic, D., Zwillenberg, L. O. (1971). Isolation of the viral causative agent from the acute form of infectious dropsy of carp. Vet. Arch. 41 (5-6): $125-138$

Haenen, O. L. M., Davidse, A. (1989). Isolation of pike fry rhabdovirus from roach (Rutilus rutilus). Bull. Eur. Ass. Fish Pathol. 9(5): 116

Hedrick, R. P., Leong, J. C., Fryer, J L. (1978). Persistent infection in salmonid fish cells with infectious pancreatic necrosis virus (IPNV). J. Fish Dis. 1: 297-308

Jørgensen, P. E. V., Olesen, N. J., Ahne, W., Lorenzen, N. (1989). SVCV and PFR viruses: serological examination of 22 isolates indicates close relationship between the two fish rhabdoviruses. In: Ahne, W., Kurstak, E. (eds.) Viruses of lower vertebrates, 1989. Int. Symp. on viruses of lower vertebrates, Aug. 1988, Munich, Germany. SpringerVerlag, Berlin, p. 349-366

Kölbl, D. (1975). Neue Erkenntnisse über die Bauchwassersucht bei Karpfen. Österr. Fisch. 28: 69-72

Negele, R. D. (1977). Histopathological changes in some organs of experimentally infected carp fingerlings with Rhabdovirus carpio. Bull. off. Int. Epiz. 87 (5/6): 449-450

Rudikov, N. I., Griscenko, I. L., Lubuncov, K. A. (1975). Vesenyaya virusnaja bolezn ryb. Byull. vses. Inst. eksp. Vet. 20: $16-19$

Manuscript first received: March 17, 1992

Revised version accepted: October 27, 1992
Responsible Subject Editor: F. M. Hetrick, College Park, Maryland, USA 